\title{
KARAKTERISTIK FISIK, KIMIA, MIKROBIOLOGI WHEY KEFIR DAN AKTIVITASNYA TERHADAP PENGHAMBATAN ANGIOTENSIN CONVERTING ENZYME (ACE)
}

\author{
[Physical, Chemical and Microbiological Characteristics of Whey Kefir \\ and Its Angiotensin Converting Enzyme (ACE) Inhibitory Activity]
}

\author{
Andi Febrisiantosa ${ }^{1) *}$, Bagus Priyo Purwanto2), Irma Isnafia Arief2) dan Yantyati Widyastuti ${ }^{3)}$ \\ 1) Program Studi Ilmu Produksi dan Teknologi Peternakan, Fakultas Peternakan, Institut Pertanian Bogor, Bogor \\ 2) Departemen Ilmu Produksi dan Teknologi Peternakan, Fakultas Peternakan, Institut Pertanian Bogor, Bogor \\ 3) Pusat Penelitian Bioteknologi - LIPI, Bogor
}

Diterima 14 Maret 2013 / Disetujui 28 Oktober 2013

\begin{abstract}
This study was conducted to evaluate the characteristics of whey-based kefir products and their activity to inhibit the angiotensin converting enzyme (ACE). Kefir was produced by using many types of whey, namely SK: skim milk based kefir (control); WK: gouda cheese whey based kefir; and WKB: commercial whey powder based kefir. The experimental design was a completely randomized design. Each treatment was conducted in triplicates. Kefirs were evaluated for physical and chemical properties ( $\mathrm{pH}$, total titratable acidity, viscosity, protein, fat, lactose, and alcohol), microbiological (lactic acid bacteria and yeast) population, peptide concentration, ACE inhibition, IC50 and Inhibition Efficiency Ratio (IER). The results showed that the types of whey used for kefir productions significantly affected the physical and chemical characteristics of the products $(p<0.05)$. Total lactic acid bacteria and yeast population of the products were not significantly different among the whey types $(p>0.05)$. The peptide concentration and ACE inhibitory activity of WK, $1.54 \pm 0.02 \mathrm{mg} / \mathrm{mL}$ and $73.07 \pm 0.91 \%$, was significantly higher $(p<0.05)$ than those of the control and WKB. The $I C_{50}$ of WK was $0.83 \pm 0.02 \mathrm{mg} / \mathrm{mL}$, significantly lower than that of control $(1.05 \pm 0.01 \mathrm{mg} / \mathrm{mL})$ and $W K B(0.96 \pm 0.01 \mathrm{mg} / \mathrm{mL})$. The IER of WK $(47.35 \pm 0.09 \%$ per $\mathrm{mg} / \mathrm{mL})$ was not significantly different $(p>0.05)$ from the control $(47.19 \pm 0.09 \%$ per $\mathrm{mg} / \mathrm{mL})$ but was significantly higher $(p<0.05)$ than that of WKB $(45.75 \pm 0.18 \%$ per $\mathrm{mg} / \mathrm{mL})$. This research indicated that whey kefir is a potential source of bioactive peptide for antihypertention agent.
\end{abstract}

Keywords: angiotensin converting enzyme, bioactive peptide, whey kefir

\begin{abstract}
ABSTRAK
Penelitian ini bertujuan untuk mengetahui karakteristik produk kefir berbahan baku whey serta kemampuannya dalam menghambat kerja Angiotensin Converting Enzyme (ACE). Produk kefir yang dibuat dalam penelitian ini berasal dari bahan baku whey yang berbeda sebagai perlakuan yang dikerjakan dalam eksperimen Rancangan Acak Lengkap 3 perlakuan dengan 3 kali ulangan, yaitu SK: Kefir berbahan baku susu skim sapi (kontrol); WK: kefir berbahan baku whey keju gouda; dan WKB: kefir berbahan baku whey bubuk komersial. Kualitas fisik dan kimia (pH, keasaman, viskositas, protein, lemak, laktosa dan alkohol), mikrobiologis (populasi bakteri asam laktat dan khamir kapang), konsentrasi peptida, penghambatan ACE, IC 50 , dan Inhibition Efficiency Ratio (IER) dari kefir yang dihasilkan kemudian diamati. Hasil penelitian menunjukkan bahwa jenis bahan baku whey yang digunakan berpengaruh nyata terhadap kualitas fisik dan kimia produk whey kefir yang diperoleh. Populasi bakteri asam laktat dan khamir kapang tidak berbeda nyata $(p>0.05)$ pada semua produk whey kefir penelitian. Konsentrasi peptida dan penghambatan ACE WK berturut-turut adalah $1.54 \pm 0.02 \mathrm{mg} / \mathrm{mL}$ dan $73.07 \pm 0.91 \%$; secara signifikan lebih tinggi $(p<0.05)$ dibandingkan dengan kontrol dan WKB. $\mathrm{IC}_{50} \mathrm{WK}$ adalah $0.83 \pm 0.02 \mathrm{mg} / \mathrm{mL}$, lebih rendah $(p<0.05)$ dibandingkan dengan kontrol $(1.05 \pm 0.01 \mathrm{mg} / \mathrm{mL})$ dan WKB $(0.96 \pm 0.01 \mathrm{mg} / \mathrm{mL})$. IER WK sebesar $47.35 \pm 0.09 \%$ per $\mathrm{mg} / \mathrm{mL}$ tidak berbeda nyata $(p>0.05)$ dibandingkan dengan kontrol $(47.19 \pm 0.09 \%$ per $\mathrm{mg} / \mathrm{mL})$ tetapi secara nyata lebih tinggi $(p<0.05)$ dibandingkan dengan WKB $(45.75 \pm 0.18 \%$ per $\mathrm{mg} / \mathrm{mL})$. Berdasarkan hasil penelitian ini dapat disimpulkan bahwa whey kefir berpotensi sebagai sumber peptida bioaktif antihipertensi.
\end{abstract}

Kata kunci: angiotensin converting enzyme, peptida bioaktif, whey kefir

\section{PENDAHULUAN}

Proses penggumpalan susu dalam pembuatan keju menghasilkan produk ikutan berupa whey. Pada beberapa industri, whey dibuang sebagai limbah. Akumulasi limbah tersebut dapat mencemari lingkungan. Whey memiliki kandungan biochemical

*Penulis Korespondensi:

Email: andifebrisiantosa@gmail.com; oxygen demand (BOD) dan chemical oxygen demand (COD) tidak memenuhi batas aman yang diperbolehkan, yaitu 50.000 $\mathrm{mg} / \mathrm{L}$ (BOD) dan $80.000 \mathrm{mg} / \mathrm{L}$ (COD) (Guimarães et al. 2010) karena whey masih mengandung nutrisi atau bahan organik diantaranya adalah protein, laktosa (gula susu) dan mineral. Bahan organik yang terkandung dalam whey merupakan media yang baik bagi pertumbuhan mikroorganisme. Hal ini berpontensi untuk pemanfaatan whey sebagai media fermentasi yang menghasilkan produk dengan nilai ekonomis lebih baik. 
Produk-produk susu fermentasi yang mengandung probiotik dan prebiotik serta memiliki dampak kesehatan mulai diminati konsumen saat ini (Ozer dan Kirmaci, 2010). Salah satu produk susu fermentasi adalah kefir. Secara tradisional, kefir dibuat dengan menambahkan starter kefir pada susu segar. Kefir telah dianjurkan untuk dikonsumsi oleh orang sehat di negara-negara Soviet untuk menurunkan risiko penyakit kronis, hipertensi, Ischeamic Heart Disease (IHD) dan alergi (Farnworth, 2005). Starter kefir memiliki komposisi protein, polisakarida dan campuran beberapa jenis mikroba. Bakteri asam laktat dan kapang yang terdapat pada starter kefir hidup bersimbiosis dan berfungsi pada proses fermentasi asam laktat dan alkohol. Starter kefir dapat memecah laktosa sehingga starter kefir tersebut dapat digunakan pula untuk fermentasi whey dari hasil pengolahan keju, yang juga kaya akan laktosa.

Peningkatan nilai ekonomis whey dapat dilakukan dengan memproduksi peptida bioaktif sebagai bahan suplemen yang memiliki fungsi kesehatan tertentu bagi manusia. Peptida tersebut memiliki peran penting dalam fungsi fisiologi dan juga fungsi regulatori dalam tubuh manusia (Tavares et al. 2011). Hidrolisis enzimatik, fermentasi atau kombinasi keduanya dapat menghasilkan golongan peptida tersebut. Pemanfaatan lebih lanjut dari peptida bioaktif adalah sebagai bahan formulasi untuk pangan fungsional dan nutraceutical (Madureira et al. 2010). Salah satu fungsi peptida tersebut adalah sebagai penghambat aktivitas ACE yang bertanggungjawab pada proses kemunculan (on set) hipertensi, terutama terkait dengan penyakit diabetes tipe 2. Beberapa penelitian telah memperlihatkan peran susu fermentasi dalam mengontrol tekanan darah. Penelitian yang dilakukan Donkor et al. (2007) terhadap BAL dalam produk susu memperlihatkan kemampuan BAL dalam menghambat aktivitas ACE. Keju Cheddar yang dibuat dari starter Lactococcus dan bakteri probiotik menghasilkan peptida penghambat ACE (Ong dan Shah, 2008). Peptida penghambat ACE juga ditemukan dalam yogurt, keju dan susu yang difermentasi oleh Lactobacillus casei ssp. rhamnosus dan strain bifidobakteria.

Informasi ilmiah yang berkaitan dengan pemanfaatan whey melalui proses fermentasi menggunakan starter kefir untuk melihat manfaat fungsional antihipertensi belum banyak dipublikasi, karena itu penelitian ini penting dilakukan. Tujuan penelitian ini adalah untuk mempelajari karakteristik fisik, kimia, mikrobiologi kefir berbahan baku whey serta mengetahui aktivitasnya terhadap penghambatan ACE.

\section{BAHAN DAN METODE}

Bahan kultur bulk kefir adalah koleksi laboratorium mikrobiologi Bagian Teknologi Hasil Ternak, Fakultas Peternakan Institut Pertanian Bogor (IPB). Bulk kefir disiapkan berdasarkan metode dalam Magalhaes et al. (2011) yaitu dengan cara mengkultivasi starter kefir dalam susu segar yang telah dipasteurisasi, disegarkan setiap hari selama 7 hari. Setelah itu bulk kefir dipisahkan dari starter kefir sebelum diinkolulasikan ke media yang baru. Media fermentasi adalah susu skim sapi dari unit proses pengolahan susu Fakultas Peternakan IPB, whey hasil ikutan proses pembuatan keju Gouda di PT Bukit Baros
Cempaka, Sukabumi dan whey bubuk komersial (Tillamook County Creamery).

\section{Rancangan percobaan dan analisa data}

Rancangan percobaan yang digunakan adalah Rancangan Acak Lengkap dengan 3 perlakuan dilakukan 3 ulangan. Perlakuan yang diberikan adalah: SK (kontrol) yaitu Kefir (bahan baku susu skim sapi); WK=Kefir (bahan baku whey cair); WKB=Kefir (bahan baku whey bubuk). Data dianalisa dengan Sidik Ragam (ANOVA), perbedaan nyata yang terjadi dilanjutkan dengan uji lanjut menggunakan uji Tukey.

\section{Pembuatan whey kefir (WK)}

Pembuatan WK mengacu pada Magalhaes et al. (2011) yang dimodifikasi. Sejumlah $500 \mathrm{~mL}$ whey dipasteurisasi pada suhu $83-85^{\circ} \mathrm{C}$ selama 30 menit, kemudian didiamkan sampai suhu mencapai $\pm 27^{\circ} \mathrm{C}$, kemudian diinokulasi dengan $5 \% \mathrm{v} / \mathrm{v}$ kultur starter bulk kefir secara aseptik, diinkubasi $\left(28^{\circ} \mathrm{C}, 20\right.$ jam). Kefir selanjutnya diperam $\left(24 \mathrm{jam}, 4^{\circ} \mathrm{C}\right)$, lalu dilakukan penyaringan menggunakan kain saring ukuran 100 mesh untuk memisahkan WK dan starter kefir.

\section{Jumlah bakteri asam laktat dan kapang khamir}

Jumlah bakteri asam laktat ditentukan dengan metode hitungan cawan menurut metode Maturin dan Peeler (2001). Sampel dan Buffered Peptone Water (BPW) diencerkan beberapa seri dilanjutkan dengan inokulasi pada media deMan Rogosa Sharpe Agar (MRSA) pada suhu $37^{\circ} \mathrm{C}$ selama $24-48$ jam. Hasil penghitungan dilaporkan menggunakan metode Standard Plate Count (SPC). Jumlah kapang khamir dihitung berdasarkan metode yang dijelaskan oleh Maturin dan Peeler (2001). Media yang digunakan adalah PDA (Potato Dextrose Agar). Sebanyak $5 \mathrm{~mL}$ sampel kefir diencerkan bersama $45 \mathrm{~mL}$ larutan BPW dan dihomogenisasi menggunakan vorteks untuk mendapatkan pengenceran P-1 sampai P-7. Inokulasi dilakukan secara aseptik pada suhu ruang selama 24 jam. Setelah mencapai waktu inkubasi 24 jam, jumlah khamir yang tumbuh kemudian dihitung.

\section{Karakteristik fisik dan kimia}

$\mathrm{pH}$ produk diukur menggunakan metode standar AOAC (2005) menggunakan pH meter (Hanna). Persentase asam laktat diukur melalui metode titrasi menggunakan $0.1 \mathrm{~N} \mathrm{NaOH}$. Jumlah asam yang diproduksi selama fermentasi dihitung dengan rumus:

$\%$ asam laktat=faktor pengenceran $\times \mathrm{V} \mathrm{NaOH} \times 0.1 \mathrm{~N}$ x 0.009 x $100 \%$

Kekentalan diukur menggunakan alat viscometer (Rion Viscotester VT-04F). Sebanyak $50 \mathrm{~mL}$ sampel dimasukkan ke dalam tempat yang tersedia pada alat dan suhu diatur pada suhu ruang. Satuan kekentalan disajikan dalam centipoise (cP). Penentuan kadar protein menggunakan metode semimikro Kjeldahl dengan faktor konversi 6.25 (AOAC, 2005). Kadar laktosa diukur menurut metode Reagen Teles. Sampel diencerkan 50 kali, direaksikan dengan $0.2 \mathrm{~mL}$ zink sulfat $5 \%$ dan 0.2 $\mathrm{mL}$ barium hidroksida $4.5 \%$. Sampel dibaca pada absorban 520 $\mathrm{nm}$. Kadar alkohol diukur menggunakan metode mikro difusi 
conway menggunakan $2 \mathrm{~mL}$ sampel yang direaksikan dengan larutan mikro difusi conway $\left(0.37 \mathrm{~g} \mathrm{~K}_{2} \mathrm{Cr}_{2} \mathrm{O}_{7}\right.$ dalam $15 \mathrm{~mL}$ air dan $28 \mathrm{~mL} \mathrm{H}_{2} \mathrm{SO}_{4}$ pekat diencerkan hingga $50 \mathrm{~mL}$ ), kemudian dibaca pada absorban $605 \mathrm{~nm}$. Kadar lemak ditentukan menggunakan metode dalam BSN (2009). Lemak dalam sampel dihidrolisa dengan amonia dan alkohol kemudian diekstraksi dengan eter. Ekstrak eter yang diperoleh kemudian diuapkan sampai kering dalam pinggan alumunium dan kadar lemak dihitung secara gravimetri.

\section{Pembuatan ekstrak whey kefir}

Kefir dihomogenkan, kemudian $\mathrm{pH}$ kefir dikondisikan hingga mencapai 4.0. Kefir kemudian dipanaskan dengan waterbath $\left(45^{\circ} \mathrm{C}\right)$ selama 10 menit diikuti dengan sentrifugasi $(5.000 \mathrm{~g}, 10$ menit $4^{\circ} \mathrm{C}$ ). Selanjutnya, larutan $\mathrm{NaOH} 0.1 \mathrm{M}$ ditambahkan hingga $\mathrm{pH}$ mencapai 7.0. Supernatan disentrifugasi lagi $(5.000$ g, 10 menit $4^{\circ} \mathrm{C}$ ) dan supernatan disimpan pada suhu $-20^{\circ} \mathrm{C}$ sampai dibutuhkan untuk analisa.

Konsentrasi peptida, penghambatan Angiotensin Converting Enzyme (ACE), IC 50 dan Inhibition Efficiency Ratio (IER)

Pengukuran konsentrasi peptida ekstrak WK dilakukan menggunakan metode uji o-phthaldialdehyde (OPA). Ekstrak WK $(30 \mu \mathrm{l})$ ditambahkan pada $1 \mathrm{~mL}$ reagen OPA di dalam cuvette $1.5 \mathrm{~mL}$. Larutan dicampurkan secara cepat dengan pembalikan cuvette dan diinkubasi pada suhu ruang selama 2 menit. Pembacaan absorbansi dilakukan pada panjang gelombang $340 \mathrm{~nm}$ menggunakan Spectrophotometer (Shimadzu UV-1601 PC). Konsentrasi peptida diestimasikan terhadap kurva standar tripton. Pengukuran aktivitas inhibitor ACE pada penelitian ini mengacu pada metode Hayes et al. (2007) yang telah dimodifikasi dalam hal konsentrasi enzim, substrat, dan bahan pelarut lainnya yang digunakan untuk uji in vitro. Substrat enzim yang digunakan untuk uji in vitro penghambatan ACE adalah Hippuryl-L-Histidyl-L-Leucine (HHL).

\section{HASIL DAN PEMBAHASAN}

\section{Karakteristik mikrobiologi whey kefir}

Mikroflora pada kefir sangat kompleks dan bervariasi. Fermentasi yang berlangsung pada proses pembuatan kefir melibatkan bakteri asam laktat dan khamir. Populasi bakteri asam laktat dan khamir produk kefir penelitian ini ditampilkan pada Gambar 1. Terlihat bahwa populasi bakteri asam laktat pada ketiga jenis produk kefir berbahan baku skim, whey dan whey bubuk tidak berbeda nyata $(p>0.05)$. Populasi bakteri asam laktat berkisar antara 9.67-11.20 $\log _{10} \mathrm{CFU} / \mathrm{mL}$. Hasil penelitian ini lebih tinggi daripada hasil penelitian Gronnevik et al. (2011), Fontan et al. (2006), dan Irigoyen et al. (2005) yang menyatakan bahwa populasi kultur starter Lactococcus spp. dan Lactobacillus spp. berturut-turut adalah 8 dan $8.5 \log _{10} \mathrm{CFU} / \mathrm{mL}$.

Populasi bakteri kultur starter dalam produk kefir yang disyaratkan dalam CODEX STAN 234-2003 adalah minimal 7 $\log _{10} \mathrm{CFU} / \mathrm{mL}$. Berdasarkan hal tersebut, produk kefir hasi penelitian ini memenuhi persyaratan CODEX. Populasi bakteri asam laktat tinggi diduga disebabkan kondisi lingkungan dan nutrisi dalam media fermentasi yang baik bagi pertumbuhan bakteri asam laktat. Bakteri asam laktat dapat melakukan regenerasi dengan cepat. Menurut Giraffa (2004), Lactobacillus adalah bakteri dominan yang ditemukan dalam hampir seluruh produk susu fermentasi dengan populasi berkisar antara 6.28 $\log _{10} \mathrm{CFU} / \mathrm{mL}$ hingga $8.32 \log _{10} \mathrm{CFU} / \mathrm{mL}$. Acetobacter, bakteri mesofilik aerob, Leuconostoc dan Lactococcus menunjukkan pertumbuhan yang sama berkisar antara $6.00 \log _{10} \mathrm{CFU} / \mathrm{mL}$ sampai $8.00 \log _{10}$ CFU/mL (Magalhaes et al. 2010).

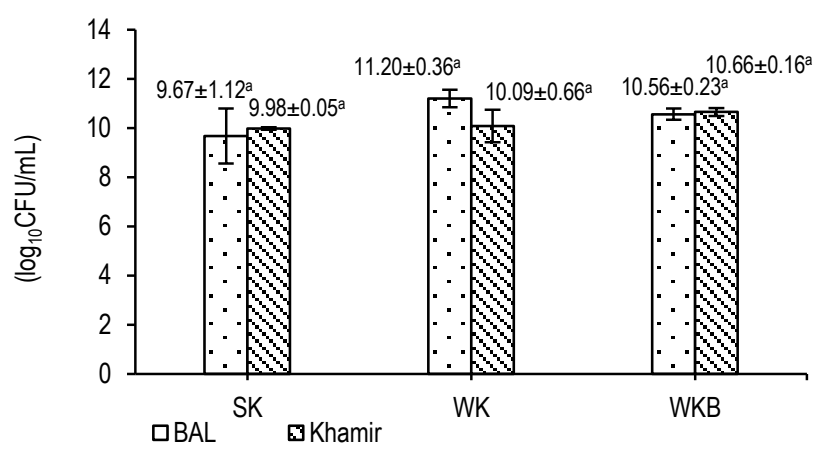

Gambar 1. Populasi bakteri asam laktat dan khamir kapang pada produk WS, WK dan WKB. Notasi huruf yang sama di atas grafik batang artinya tidak berbeda nyata $(p>0.05), n=9$

Populasi khamir pada ketiga jenis produk kefir tidak berbeda nyata $(p>0.05)$. Menurut CODEX STAN 234-2003, populasi khamir minimal $10^{4} \mathrm{CFU} / g$. Rata-rata populasi khamir pada awal fermentasi adalah $6.00 \log _{10} \mathrm{CFU} / \mathrm{mL}$ dan meningkat $7.31 \log _{10}$ CFU/mL pada akhir fermentasi selama 24 jam (Giraffa, 2004). Magalhaes et al. (2010) menyatakan bahwa populasi khamir pada produk kefir adalah $5-6 \log _{10} \mathrm{CFU} / \mathrm{mL}$. Populasi khamir kefir dari sari kedelai yang diinokulasi dengan starter kefir adalah $3.20 \log _{10} \mathrm{CFU} / \mathrm{mL}$ (Kasenkas et al. 2011). Populasi khamir pada kefir hasil penelitian ini sesuai dengan standar CODEX dan lebih tinggi dari hasil penelitian Giraffa (2004), Magalhaes et al. (2010), dan Kasenkas et al. (2011). Selama fermentasi, pertumbuhan khamir distimulasi oleh kondisi asam yang diakibatkan aktivitas bakteri asam laktat, sebaliknya pertumbuhan bakteri dapat distimulasi dengan keberadaan khamir khususnya khamir yang dapat mensintesis komponen penting bagi pertumbuhan bakteri seperti vitamin dan nitrogen terlarut (Almeida et al. 2007).

Komposisi populasi bakteri asam laktat dan khamir pada produk kefir penelitian ini relatif seimbang yaitu 1:1. Stepaniak and Fetlinski (2002) menyatakan bahwa distribusi mikroorganisme dalam matriks pada starter kefir tidak seragam. $L b$. kefiranofaciens terdistribusi menyebar pada starter kefir tetapi populasinya paling tinggi di tengah-tengah, sedangkan Lb. kefir pada umumnya tumbuh di permukaan starter kefir. Komposisi spesifik mikroflora dari starter kefir sangat tergantung pada negara asal, cara kultivasi, dan teknik penyimpanan, tetapi perbandingan jumlah khamir dan bakteri asam laktat $(\mathrm{BAL})$ relatif stabil.

\section{Karakteristik fisik dan kimia whey kefir}

Sifat fisik dan kimia kefir meliputi total solid, laktosa, protein, lemak, mineral, alkohol, $\mathrm{pH}$, viskositas dan keasaman produk dianalisa. Rataan nilai hasil analisa disajikan pada Tabel 1. 
Tabel 1. Karaketristik fisik dan kimia produk kefir berbahan baku susu skim segar, whey segar dan whey bubuk

\begin{tabular}{lccc}
\hline \multirow{2}{*}{ Parameter } & \multicolumn{3}{c}{ Produk Kefir } \\
\cline { 2 - 4 } & SK & WK & WKB \\
\hline pH & $3.95 \pm 0.07^{\mathrm{a}}$ & $4.00 \pm 0.01^{\mathrm{a}}$ & $4.74 \pm 0.04^{\mathrm{b}}$ \\
Viskositas (cP) & $1.550 .00 \pm 180.28^{\mathrm{b}}$ & $350.00 \pm 0.00^{\mathrm{a}}$ & $350.00 \pm 0.00^{\mathrm{a}}$ \\
Asam laktat (\%) & $1.11 \pm 0.04^{\mathrm{a}}$ & $1.13 \pm 0.00^{\mathrm{a}}$ & $1.11 \pm 0.02^{\mathrm{a}}$ \\
Total padatan $(\%)$ & $8.92 \pm 0.14^{\mathrm{a}}$ & $14.64 \pm 0.13^{\mathrm{b}}$ & $20.17 \pm 1.84^{\mathrm{c}}$ \\
Laktosa $(\% \mathrm{bb})$ & $0.34 \pm 0.10^{\mathrm{a}}$ & $1.82 \pm 0.29^{\mathrm{b}}$ & $2.69 \pm 0.48^{\mathrm{c}}$ \\
Protein $(\% \mathrm{bb})$ & $3.31 \pm 0.15^{\mathrm{a}}$ & $2.63 \pm 0.72^{\mathrm{a}}$ & $2.93 \pm 0.21^{\mathrm{a}}$ \\
Lemak $(\% \mathrm{bb})$ & $0.46 \pm 0.18^{\mathrm{a}}$ & $1.70 \pm 0.14^{\mathrm{b}}$ & $0.45 \pm 0.09^{\mathrm{a}}$ \\
Mineral $(\% \mathrm{bb})$ & $0.83 \pm 0.02^{\mathrm{a}}$ & $1.15 \pm 0.06^{\mathrm{b}}$ & $1.78 \pm 0.08^{\mathrm{c}}$ \\
Alkohol $(\%)$ & $<0.5$ & $<0.5$ & $<0.5$ \\
\hline
\end{tabular}

Keterangan: SK: Kefir berbahan baku susu skim; WK: Whey kefir berbahan baku whey segar; WKB: Whey kefir berbahan baku whey bubuk. Angkaangka pada baris yang sama yang diikuti oleh huruf yang sama tidak berbeda nyata pada taraf uji $5 \%$ (uji lanjut Tukey), $n=9$

Berlangsungnya proses fermentasi ditandai dengan terjadinya penurunan $\mathrm{pH}$. Kultur starter yang diberikan pada media fermentasi menghasilkan asam laktat dalam jumlah tertentu sehingga menurunkan $\mathrm{pH}$ sehingga mencapai $\mathrm{pH}$ 3.8-4.2. Produk kefir pada penelitian ini memiliki pH berkisar antara 3.95-4.74. Whey kefir yang dibuat dari bahan baku whey (WK) menghasilkan $\mathrm{pH}$ akhir 4.00. $\mathrm{pH}$ kefir yang dibuat dari sari kedelai berkisar antara 4.58-4.65 (Kesenkas et al. 2011). Ismaiel et al. (2011) menyatakan bahwa pH kefir dengan bahan baku kelapa, sari kedelai, dan whey berturut-turut adalah 3.21 ; 3.11 dan 3.01 .

Keasaman kefir dihitung sebagai \% asam laktat. Kefir yang dihasilkan pada penelitian ini memiliki keasaman antara 1.11\% sampai $1.13 \%$. Kadar asam laktat meningkat karena aktivitas mikroba selama proses fermentasi yang menguraikan laktosa menjadi glukosa dan galaktosa untuk kemudian dimetabolisme menjadi asam laktat. Oleh karena itu, kadar laktosa produk kefir yang dihasilkan menurun seiring dengan peningkatan keasaman. Kefir dalam penelitian ini memiliki kadar laktosa 0.342.69\%. Berdasarkan CODEX STAN 234-2003, keasaman sebagai $\%$ asam laktat pada kefir minimal $0.6 \%$, kadar laktosa kefir berkisar 3.0-3.9\% dan kadar asam laktat 0.73-1.15\%. Menurut Purnomo dan Muslimin (2012), kadar laktosa kefir berbahan baku susu kambing adalah $4.3 \%$ dengan kadar asam laktat $0.76 \%$.

Berdasarkan CODEX STAN 234-2003, komposisi protein kefir minimal $2.7 \%$. Komposisi protein kefir pada penelitian ini berkisar antara 2.63-3.31\%. Hasil penelitian Kesenkas et al. (2011) memperlihatkan bahwa kadar protein kefir berbahan baku susu sapi adalah $4.10 \%$ sedangkan kefir berbahan baku campuran susu dan sari kedelai (rasio 1:1) adalah 4.03\%. Kadar protein WK (2.63\%) yang lebih rendah dibandingkan standar dalam CODEX dan Kesenkas et al. (2011) karena kandungan protein bahan baku whey yang juga rendah. Selain itu, protein whey bersifat sukar untuk didegradasi dibandingkan protein kasein (Kesenkas et al. 2011). Kadar lemak yang ditetapkan dalam CODEX STAN 234-2003 adalah kurang dari $10 \%$. Kadar lemak produk kefir dalam penelitian ini berkisar antara $0.45-1.7 \%$ memenuhi ketentuan dalam CODEX. Kadar lemak tersebut jauh lebih rendah dibandingkan dengan hasil penelitian Kesenkas et al. (2011), yaitu 3.05\%.
Viskositas kefir SK lebih tinggi dibandingkan WK dan WKB. Terlihat bahwa semakin rendah $\mathrm{pH}$ menghasilkan kefir dengan viskositas semakin tinggi. Hal tersebut berkaitan dengan aktivitas mikroba yang tumbuh pada saat fermentasi dan komposisi bahan baku (Ismaiel et al. 2011). Iličić et al. (2008) menyatakan bahwa viskositas dan struktur gel pada produk susu fermentasi dipengaruhi oleh beberapa faktor yaitu komposisi susu, konsentrasi kasein, suhu inkubasi, perlakuan panas, keasaman serta jenis kultur yang digunakan.

Komponen penting pada susu adalah kasein. Selama proses fermentasi terjadi penggumpalan kasein dan peningkatan kekentalan produk. Susu skim sebagai bahan baku yang digunakan pada SK kaya akan kasein sedangkan whey untuk WK dan WKB telah kehilangan banyak kasein. Peningkatan viskositas produk susu fermentasi diperoleh pada produk dengan rasio kandungan kasein dan protein whey sebanyak 80:20 (Bonisch et al. 2006). Rasio kasein dan whey pada produk hasil penelitian ini lebih rendah khususnya pada produk WK dan WKB. Selain itu, menurut Ismaiel et al. (2011), massa molar dari eksopolisakarida diduga kuat mempengaruhi viskositas produk susu fermentasi, polimer yang memiliki massa molar tinggi menjadikan produk dengan viskositas tinggi. Pada kefir eksopolimer dapat diperoleh jika terdapat mikroba penghasil eksopolimer seperti Acetobacter sp. Keberadaan 1\% Acetobacter pasteurianus dari total mikroba pada starter kefir memegang peranan penting dalam meningkatkan rasa dan konsistensi kefir melalui peningkatan viskositas. Bakteri jenis Acetobacter kemungkinan tumbuh lebih banyak pada SK dibandingkan WK dan SKB.

Kandungan alkohol produk kefir pada penelitian ini kurang dari $0.1 \%$ (Tabel 1). Kefir yang sudah matang mengandung $0.8-1 \%$ asam laktat. Kefir tradisional yang diproduksi langsung dari starter kefir mengandung etanol sampai 2\% sedangkan produk kefir dari industri mengandung $0.04-0.15 \%$ asam asetat, $0.4 \% \mathrm{CO}_{2}, 1-4 \mathrm{mg} / \mathrm{L}$ diasetat dan beberapa $\mathrm{mg} / \mathrm{L}$ asetaldehid (Stepaniak dan Fetlinski, 2002). Kandungan alkohol yang rendah disebabkan waktu pematangan setelah inkubasi kurang. Menurut Stepaniak dan Fetlinski (2002), produksi alkohol juga berlangsung selama proses pematangan dan penyimpanan di suhu rendah. Alkohol merupakan produk akhir dari aktivitas khamir. Khamir tumbuh baik pada lingkungan dengan suhu lebih rendah. Suhu inkubasi yang digunakan pada penelitian ini adalah $28^{\circ} \mathrm{C}$. Hasil penelitian Purnomo dan Muslimin (2012) menunjukkan kefir yang diinkubasi pada suhu $24^{\circ} \mathrm{C}$ memiliki kadar alkohol 0.94\%. Stepaniak dan Fetlinski (2002) juga menyatakan bahwa Candida kefyr menstimulasi pertumbuhan Lb. kefir. Produksi etanol dari Can. kefyr lebih tinggi jika khamir tersebut berkembang bersamaan dengan $L b$. kefir. Kultur starter yang digunakan pada penelitian ini memiliki komposisi Lactobacillus sp. $35.4 \%$, Streptococcus sp. $58.3 \%$ dan khamir 6.3\%. Interaksi Can. kefyr dan Lb. kefir untuk menghasilkan kadar alkohol tinggi tidak terjadi sehingga kadar alkohol yang dihasilkan rendah.

Kandungan mineral produk kefir dalam penelitian ini berkisar antara $0.83-1.78 \%$. Belum ada standar yang mengatur kadar mineral dalam produk kefir. Menurut Robinson et al. (2002), aktivitas metabolisme kultur probiotik dapat meningkatkan produksi atau bioavailabilitas beberapa vitamin dan mineral 
serta memperbaiki kecernaan protein. Peningkatan vitamin dalam kefir telah diteliti oleh Stepaniak dan Fetlinski (2002) yang menyatakan bahwa kandungan vitamin $B_{1}, B_{2}$ dan asam folat pada kefir lebih tinggi dibandingkan pada susu.

Konsentrasi peptida, penghambatan Angiotensin Converting Enzyme (ACE), IC 50 dan Inhibition Efficiency Ratio (IER)

ACE memegang peranan penting fungsi regulasi tekanan darah dalam tubuh. Pada kondisi abnormal, kerja ACE berlebih sehingga dapat menimbulkan dampak tekanan darah tinggi. Penghambatan ACE adalah salah satu cara untuk menurunkan risiko terjadinya tekanan darah tinggi. Beberapa jenis peptida fungsional yang berperan dalam penurunan tekanan darah, absorbsi kalsium dan regulasi kolesterol serum darah telah berhasil diisolasi dari susu dan hidrolisat kedelai (Kim et al. 2011). Konsentrasi peptida yang dibutuhkan untuk menghambat $50 \%$ kerja ACE disebut $I_{50}$. Konsentrasi peptida, penghambatan ACE, IER, dan $\mathrm{IC}_{50}$ ekstrak whey kefir dalam penelitian ini disajikan pada Tabel 2.

Tabel 2. Konsentrasi peptida, penghambatan ACE, Inhibition Efficiency Ratio (IER) dan IC 50 ekstrak produk whey kefir

\begin{tabular}{lcccc}
\hline & $\begin{array}{c}\text { Konsentrasi } \\
\text { Peptida } \\
(\mathrm{mg} / \mathrm{mL})\end{array}$ & $\begin{array}{c}\text { Penghambatan } \\
\text { ACE }(\%)\end{array}$ & $\begin{array}{c}\text { IC }) \\
(\mathrm{mg} / \mathrm{mL})\end{array}$ & $\begin{array}{c}\text { IER } \\
(\% \text { per } \\
\text { mg/mL })\end{array}$ \\
\hline SK & $0.97 \pm 0.02^{\mathrm{a}}$ & $45.94 \pm 0.81^{\mathrm{a}}$ & $1.05 \pm 0.01^{\mathrm{c}}$ & $47.19 \pm 0.09^{\mathrm{b}}$ \\
WK & $1.54 \pm 0.02^{\mathrm{c}}$ & $73.07 \pm 0.91^{\mathrm{c}}$ & $0.83 \pm 0.02^{\mathrm{a}}$ & $47.35 \pm 0.09^{\mathrm{b}}$ \\
WKB & $1.25 \pm 0.02^{\mathrm{b}}$ & $57.04 \pm 1.11^{\mathrm{b}}$ & $0.96 \pm 0.01^{\mathrm{b}}$ & $45.75 \pm 0.18^{\mathrm{a}}$ \\
\hline
\end{tabular}

Keterangan: Angka-angka pada kolom yang sama yang diikuti oleh huruf yang sama tidak berbeda nyata pada taraf uji $5 \%$ (uji lanjut Tukey), $n=9$

Jenis bahan baku whey yang digunakan berpengaruh nyata $(p<0.05)$ pada konsentrasi peptida ekstrak whey kefir. Konsentrasi peptida tertinggi dicapai untuk WK (1.54 \pm 0.02 $\mathrm{mg} / \mathrm{mL}$ ). Konsentrasi peptida tinggi diduga berkaitan dengan pertumbuhan biomassa mikroba kefir yang tinggi pula pada media whey. Sintesis protein mikroba yang berkembang selama proses fermentasi memberikan kontribusi pada peningkatan konsentrasi peptida produk whey kefir.

Jenis bahan baku whey yang digunakan berpengaruh nyata $(p<0.05)$ pada penghambatan ACE ekstrak whey kefir. Penghambatan ACE tertinggi dicapai untuk WK (73.07士0.91\%). Penghambatan ACE sebanding dengan konsentrasi peptida whey kefir hasil penelitian ini. Peptida bioaktif yang terdapat pada WK diduga merupakan peptida yang memiliki sifat fungsional menghambat kerja ACE. Menurut Quiros et al. (2005), potensi terbesar peptida penghambat ACE dihasilkan dari protein susu yang difermentasi dengan beberapa strain isolat Lactobacullis helveticus atau kombinasi dengan khamir Saccharomyces cereviceae. Aktivitas penghambatan ACE pada kefir berkaitan juga dengan kombinasi protein sel beberapa strain bakteri asam laktat dan khamir yang berkembang selama proses susu fermentasi. Hirota et al. (2007) menyatakan bahwa hidrolisat yang mengandung asam amino Val-Pro-Pro dan llePro-Pro menunjukkan perbaikan disfungsi endothelial vascular pada pasien hipertensi. Saat ini, peptida antihipertensi dapat diproduksi menggunakan teknologi DNA rekombinan, yaitu fusi protein rekombinan diekspresikan dalam Escherichia coli, untuk kemudian dipurifikasi dan dirombak oleh enzim proteinase dari L. helveticus terseleksi (Losacco et al. 2007).

$\mathrm{IC}_{50}$ menggambarkan konsentrasi peptida yang diperlukan untuk menghambat $50 \%$ kerja ACE. Nilai $\mathrm{IC}_{50}$ dihitung dengan cara memasukkan nilai 50 pada persamaan linear hubungan nilai konsentrasi peptida dan penghambatan ACE. Jenis whey yang digunakan berpengaruh nyata $(p<0.05)$ pada nilai $\mathrm{IC}_{50}$ ekstrak whey kefir penelitian ini. $\mathrm{IC}_{50}$ terendah dicapai untuk WK $(0.83 \pm 0.02 \mathrm{mg} / \mathrm{mL})$. Nilai $\mathrm{IC}_{50}$ berbanding terbalik dengan nilai IER. Hal tersebut menggambarkan bahwa peptida yang terkandung dalam WK adalah peptida aktif yang memiliki sifat penghambatan ACE. Nilai $\mathrm{IC}_{50}$ WK lebih rendah jika dibandingkan dengan SK dan WKB sebab proses fermentasi yang terjadi pada WK menghasilkan lebih banyak peptida sederhana penghambat ACE. Papadimitriou et al. (2007) melaporkan nilai $\mathrm{IC}_{50}$ ekstrak larut air dari yoghurt susu berkisar antara 1.49-1.62 mg/mL. Ekstrak larut air dari kefir susu kambing memiliki nilai $\mathrm{IC}_{50}$ sebesar $0.365 \mathrm{mg} / \mathrm{mL}$ (Quiros et al. 2005). Hasil penelitian Tavares et al. (2011) memperlihatkan bahwa hidrolisat "whey protein concentrate" (WPC) memiliki nilai $\mathrm{IC}_{50}$ sebesar $52.9 \pm 2.9 \mu \mathrm{g} / \mathrm{mL}$, tetapi fraksi peptidanya dengan berat molekul di bawah $3 \mathrm{kDa}$ menunjukkan nilai $\mathrm{IC}_{50}$ sebesar $23.6 \pm 1.1 \mu \mathrm{g} / \mathrm{mL}$. Ditemukan pula 3 jenis peptida yang berpotensi sebagai peptida antihipertensi diantaranya berasal dari a-lactalbumin $\mathrm{f}(16-26)$ dengan sekuen KGYGGVSLPEW yang memiliki nilai $I_{50} 0.80 \pm 0.1 \mu \mathrm{g} / \mathrm{mL}$, a-lactalbumin $\mathrm{f}(97-104)$ sekuen DKVGINYW dengan nilai $\mathrm{IC}_{50} 25.2 \pm 1.0 \mu \mathrm{g} / \mathrm{mL}$ dan $\alpha-$ lactoglobulin $\mathrm{f}(33-42)$ sekuen DAQSAPLRVY dengan nilai $\mathrm{IC}_{50}$ $13.0 \pm 1.0 \mu \mathrm{g} / \mathrm{mL}$

IER menggambarkan rasio efisiensi penghambatan ekstrak whey kefir terhadap ACE. Nilai IER diperoleh dengan cara membagi nilai penghambatan ACE dengan konsentrasi peptida. Semakin tinggi nilai IER, maka semakin tinggi tingkat efisiensi penghambatannya terhadap ACE. Jenis whey yang digunakan berpengaruh nyata $(p<0.05)$ pada nilai IER ekstrak whey kefir penelitian ini. IER tertinggi dicapai untuk WK $(47.35 \pm 0.09 \%$ per $\mathrm{mg} / \mathrm{mL})$, berbeda nyata dengan WKB $(45.75 \pm 0.18 \%$ per $\mathrm{mg} / \mathrm{mL})$, namun tidak berbeda nyata dengan SK $(47.19 \pm 0.09 \%$ per $\mathrm{mg} / \mathrm{mL}$ ). Selain memiliki sifat penghambatan ACE yang tinggi, WK juga memiliki IER yang tinggi. Hal tersebut menunjukkan bahwa peptida yang terkandung dalam WK diduga adalah golongan peptida yang memiliki sifat fungsional penghambat ACE. Menurut Chen et al. (2007), peptida penghambat ACE dari susu fermentasi tersusun atas tiga asam amino yaitu Gly-Thr-Trp dan Gly-Val-Trp dengan nilai IC 50 berturut-turut $0.0884 \mathrm{mg} / \mathrm{mL}$ dan $0.185 \mathrm{mg} / \mathrm{mL}$. Peptida tersebut dapat menghambat ACE membentuk angiotensin II dan mendegradasi bradikinin sebagai subtrat kompetitif bagi ACE (Brown dan Vaughan, 1998). Lebih lanjut Chen et al. (2007) menyatakan bahwa terjadi perbedaan nyata tekanan darah diastolik yaitu tikus percobaan yang mengonsumsi susu fermentasi selama 8 minggu dengan dosis konsentrasi peptida $5 \mathrm{mg} / \mathrm{mL}$ per hari memiliki diastolik lebih rendah. 


\section{KESIMPULAN}

Whey dapat dikembangkan menjadi produk whey kefir melalui proses fermentasi. Whey kefir yang diproduksi berpotensi dimanfaatkan sebagai sumber peptida bioaktif antihipertensi. Jenis whey yang digunakan menentukan aktivitas penghambatan ACE secara in vitro whey kefir yang diproduksi. Whey kefir yang dibuat dari whey cair segar hasil ikutan pembuatan keju Gouda menunjukkan kualitas penghambatan ACE sebanding dengan kefir berbahan baku susu skim serta lebih baik dibandingkan whey kefir berbahan baku whey bubuk komersial.

\section{UCAPAN TERIMA KASIH}

Penulis menghaturkan penghargaan kepada Ibu Dr. Ir. Rarah Ratih Adjie Maheswari, Alm. dari Fakultas Peternakan IPB, atas arahan, bimbingan dan nasihatnya. Terima kasih kepada Bapak Yuny Erwanto, SPt, MP, PhD. dari Laboratorium Teknologi Hasil Ikutan dan Lingkungan, Fakultas Peternakan UGM atas bantuannya pada analisis pengujian penghambatan ACE.

\section{DAFTAR PUSTAKA}

Almeida EG, Rachid CCTC, Schwan RF. 2007. Microbial population present in fermented beverage 'cauim' produced by Brazilian Amerindians. Int J Food Microbiol 120: 146-151. DOI: 10.1016/j.ijfoodmicro.2007.06.020.

[AOAC] Association of Official Analytical Chemists. 2005. Official Methods of Analysis of AOAC International. 18 Edition. Gaithersburg, USA:AOAC International: 2464.

Bonisch MP, Huss M, Lauber S, Kulozik U. 2006. Yoghurt gel formation by means of enzymatic protein cross-linking during microbial fermentation. J Food Hydrocolloid 21: 585595. DOI: 10.1016/j.foodhyd.2006.07.002.

[BSN] Badan Standardisasi Nasional. 2009. SNI 2981:2009: Yoghurt. Badan Standardisasi Nasional, Jakarta.

Chen GW, Tsai JS, Pan BS. 2007. Purification of angiotensin Iconverting enzyme inhibitory peptides and antihypertensive effect of milk produced by protease-facilitated lactic fermentation. Int Dairy J 17: 641-647. DOI: 10.1016/j.idairyj. 2006.07.004.

Donkor ON, Henriksson A, Vasiljevic T, Shah NP. 2007. agalactosidase and proteolytic activities of selected probiotic and dairy cultures in fermented soymilk. Food Chem 104: 10-20. DOI: 10.1016/j.foodchem.2006.10.065.

Farnworth ER. 2005. Kefir - a complex probiotic. Food Sci Technol Bull: Functional Foods 2: 1-17. DOI: 10.1616/14762137.13938.

Fontan MCG, Martinez S, Franco I, Carballo J. 2006. Microbiological and chemical changes during the manufacture of kefir made from cows' milk, using a commercial starter culture. Int Dairy J 16: 762-767. DOI: 10.1016/j.idairyj.2005.07.004.
Giraffa G. 2004. Studying the dynamics of microbial populations during food fermentation. FEMS Microbiol Rev 28: 251-260. DOI: 10.1016/j.femsre.2003.10.005.

Gronnevik H, Falstad M, Narvhus JA. 2011. Microbiological and chemical properties of Norwegian kefir during storage. Int Dairy J 21: 601-606. DOI: 10.1016/j.idairyj.2011.01.001.

Guimarães PMR, Teixeira JA, Domingues L. 2010. Fermentation of lactose to bio-ethanol by yeasts as part of integrated solutions for the valorisation of cheese whey. Biotechnol Adv 28: 375-384. DOI: 10.1016/j.biotechadv. 2010.02.002.

Hayes M, Stanton C, Slattery H, O'Sullivan O, Hill C, Fitzgerald GF, Ross RP. 2007. Casein fermentate of Lactobacillus animalis DPC6134 contains a range of novel propeptide angiotensin-converting enzyme inhibitors. Appl Environ Micrbiol 73: 4658-4667. DOI: 10.1128/AEM.00096-07.

Hirota T, Ohki K, Kawagishi R, Kajimoto Y, Mizuno S, Nakamura Y, Kitakaze M. 2007. Casein hydrolysate containing the antihypertensive tripeptides Val-Pro-Pro and Ile-Pro-Pro improves vascular endothelial function independent of blood pressure-lowering effects: contribution of the inhibitory action of angiotensin-converting enzyme. Hypertens Res 30: 489-496. DOI: 10.1291/hypres.30.489.

Iličić MD, Caric MD, Milanovic SD, Dokic LP, Duric MS. Bosnjak GS, Durakovic KG. 2008. Viscosity changes of probiotic yoghurt with transglutaminase during storage. Acta Periodica Technol 39: 1-19. DOI: 10.2298/APT0839011l.

Irigoyen A, Arana I, Castiella M, Torre P, Ibanez FC. 2005. Microbiological, physicochemical, and sensory characteristics of kefir during storage. Food Chem 90: 613-620. DOI: 10.1016/j.foodchem.2004.04.021.

Ismaiel AA, Ghaly MF, El-Naggar AK. 2011. Some physicochemical analyses of kefir produced under different fermentation conditions. J Sci Indust Res 70: 365-372.

Kesenkas H, Dinkci N, Seckin K, Kinik O, Gonc S, Ergonul PG, Kavas G. 2011. Physicochemical, microbiological, and sensory characteristics of soymilk kefir. Afr J Microbiol Res 5: 3737-3746. DOI: 10.5897/AJMR11.579.

Kim YK, Lim CW, Yeun SM, Lee MH, Moon HS, Cho HA, Yoon NY, Yoon DH, Park HY, Lee DS. 2011. Dipeptide (Tyr-lle) acting as an inhibitor of Angiotensin-I-Converting Enzyme (ACE) from the hydrolysate of jellyfish Nemopilema nomurai. Fish Aquat Sci 14: 283-288. DOI: 10.5657/FAS. 2011.0283.

Losacco M, Gallerani R, Gobbetti M, Minervini F, De Leo F. 2007. Production of active angiotensin-I converting enzyme inhibitory peptides derived from bovine beta-casein by recombinant DNA technologies. Biotech J 2: 11 1425-1434.

Madureira AR, Tavares T, Gomes AMP, Pintado ME, Malcata FX. 2010. Invited review: physiological properties of bioactive peptides obtained from whey proteins. J Dairy Sci 93: 437-455. DOI: 10.3168/jds.2009-2566.

Magalhaes KT, Pereira GVM, Dias DR, Schwan RF. 2010. Microbial communities and chemical changes during fermentation of sugary Brazilian kefir. World J Microbiol 
Biotechnol 26: 1241-1250. DOI: 10.1007/s11274-009-0294$\mathrm{x}$.

Magalhaes TM, Dragone G, Pereira GVM, Oliveira JM, Domingues L, Teixeira JA, e Silva JBA, Schwan RF. 2011. Comparative study of the biochemical changes and volatile compound formations during the production of novel wheybased kefir beverages and traditional milk kefir. Food Chem 126: 249-253. DOI: 10.1016/j.foodchem.2010.11.012.

Maturin L, Peeler JT. 2001. Aerobic Plate Count. BAM (Bacteriological Analytical Manual), Chapter 3. Food and Drug Administration.

Ong L, Shah NP. 2008. Release and identification of angiotensin-converting enzyme-inhibitory peptides as influenced by ripening temperatures and probioticts adjuncts in cheddar cheeses. LWT-Food Sci Technol 41: 1555-1566. DOI: 10.1016/j.Iwt.2007.11.026.

Ozer BH, Kirmaci HA. 2010. Functional milks and dairy beverages. Int J Dairy Technol 63: 1-15. DOI: 10.1111/j. 1471-0307.2009.00547.x.
Papadimitriou CG, Mastrojiannaki AV, Silva SV, Gomes AM, Malcata FX, Alichanidis SV. 2007. Identification of peptides in traditional and probiotic sheep milk yoghurt with angiotensin I-converting enzyme (ACE)-inhibitory activity. Food Chem 105: 647-656. DOI: 10.1016/j.foodchem.2007. 04.028.

Purnomo H, Muslimin LD. 2012. Chemical characteristics of pasteurised goat milk kefir prepared using different amount of Indonesian kefir grains and incubation times. Int Food Res J 19: 791-794.

Quiros A, Hernandez-Ledesma B, Ramos M, Amigo L, Recio I. 2005. Angiotensin-converting enzyme inhibitory activity of peptides derived from caprine kefir. J Dairy Sci 88: 34803487. DOI: 10.3168/jds.S0022-0302(05)73032-0.

Tavares T, Contreras MM, Amorim M, Pintado M, Recio I, Malcata FX. 2011. Novel whey-derived peptides with inhibitory effect against angiotensin-converting enzyme: In vitro effect and stability to gastrointestinal enzymes. Peptides 32: 1013-1019. DOI: 10.1016/j.peptides.2011. 02.005 . 